\title{
Evaluation Of Heavy Metals Concenteratioin In Fish From Alexandria Coast, Egypt
}

\author{
E.E.Siam \\ Assistant professor in marine environmental protection program. \\ Arab academy for science and technology and maritime transport
}

\begin{abstract}
Cadmium $\mathrm{Cu}, \mathrm{Fe}, \mathrm{Mn}, \mathrm{Pb}$ concentrations were determined in the muscles and organs (gills, liver, stomach and brain), of five fish species collected from Alexandria coast (El-Mex Bay) in December 2000. Four of them are carnivorous namely, Diplodus sargus, Sparus auratus, Dicentrachus punctatus, and Mugil capito, while the last one Siganus rivulatus is herbivorous. The results indicated high level of accumulation of these metals in the different organs of all studied fish, with respect to their correspondings in the muscle tissues. The accumulation factors for these metals were higher in the herbivorous fish. The essential metals ( $\mathrm{Fe}, \mathrm{Cu}$, and $\mathrm{Mn})$ were the more pronounced ones reflecting increase the trophic level of the fish. Lead concentration ranged from 1.2-3.5 mg/kg in the stomach and brain while it ranged from $0.4-0.9 \mathrm{mg} / \mathrm{kg}$ in fish muscles. Also, Cd level was generally lower than that of $\mathrm{Pb}$ in various organs while brain gained the highest values. Both of these toxic metals $\mathrm{Pb}$ and $\mathrm{Cd}$ were of higher values in the herbivorous fish than in carnivorous ones. Most of the fish generally showed levels of $\mathrm{Cd}$ in the organs which are close to that of the recommended standard $(2.0 \mathrm{mg} / \mathrm{kg})$ of the National Health and Medical Council in Australia, (NHMRC). However, none of them contained Cd concentrations above $0.5 \mathrm{mg} / \mathrm{kg}$ in their muscle tissues. Comparing the human metal intake due to consumption rate of fish muscles with the permissible level of a Provisional Tolerable Weekly Intake (PTWI) demonstrated that, the human consumption of these fish is still safe.
\end{abstract}

\section{Introduction}

Studies of heavy metals in fish are an important aspect of environmental pollution control, because human activities progressively increase the concentrations of heavy metals in aquatic system. (El-Nabawi et al 1987). Also, knowledge of levels of pollutants in edible marine organisms is important from a public health protection view point. In addition, the distribution of trace elements, particularly within the tissues of marine animals, is of interest in understanding the role they play in the biochemical and physiological mechanisms of the organism (Emara et al 1993). Moreover, the amount of these elements reaching man by the food chain these trace contaminants may have effects on the ecosystem greater than those of the common pollutants.

Aquatic organisms require cert ain trace metals to maintain normal metabolism. When present in excess, however, these essential metals such as $\mathrm{Fe}, \mathrm{Cu}$, and $\mathrm{Mn}$ may exert toxic effects. As to the metals, which are known to be harmful like $\mathrm{Cd}$ and $\mathrm{Pb}$, their toxicity rises with their concentration in an accessible form. Many of them are known to be concentrated by marine

Refree : Prof ; Dr. Abla M. Helmy Afify 
organisms in food chain (Morales, 1980, Uysal, 1980, Emara, 1982, Shriadah and Emara, 1992 and El-Rayis et al., 1997). In Alexandria Coast, ElMex Bay (see figure 1), pollution by heavy metals may be derived from anthropogenic activities, due to industrial and agricultural drainage waters, and domestic effluents via different land based sources.

Two thirds of the Alexandria municipality wastewater is released after primary treatment into an inland lake called Lake Maryout prior to pumping into El-Mex Bay, (west of the city), together with agricultural runoff drained from the north-west part of the Nile delta. Part of the third of the Alexandria wastewater goes to the bay without treatment via neighbouring Western Harbour. The daily discharge rate from El-Mex Pumping Station to the bay is about 6 million cubic meters. Many investigations for the environ mental conditions and levels of heavy metals in fish of the El-Mex bay have been carried out by several authors like (El-Rayis et al., 1986, Abuldahab et al, 1990, and El-Rayis et al., 1997). The present work is devoted to investigation of the level of $\mathrm{Fe}, \mathrm{Cu}, \mathrm{Mn}, \mathrm{Pb}$ and $\mathrm{Cd}$ in muscle tissues and different organs for each of the edible and of commercial value fish Diplodus sargus, Sparus auratus, Dicentrachus punctatus, and Mugil capito, (as carnivorous fish) and Siganus rivulatus (as herbivorous fish) from El-Mex Bay area.

\section{Materials and Methods}

Samples of the selected commercial fish Diplodus sargus, Sparus auratus, Dicentrachus punc tatus, Mugil capito and Siganus rivulatus, were collected once in December, 1999 from local fishermen of El-Mex Bay, Alexandria (figure1), and kept frozen $\left(-20^{\circ} \mathrm{C}\right)$ prior to subjection to metal analysis. The analysis was commenced according to Bernhard (1976). The different organs, (liver, gills, stomach and brain) and muscle tissues were sampled by section from at least 6 individuals of each fish species (see table 1), then mixed to make a composite sample (UNEP, 1984, El-Nabawai et al., 1987, EPA, 1991 and Tayel, 1995). From each composite sample, $2 \mathrm{~g}$

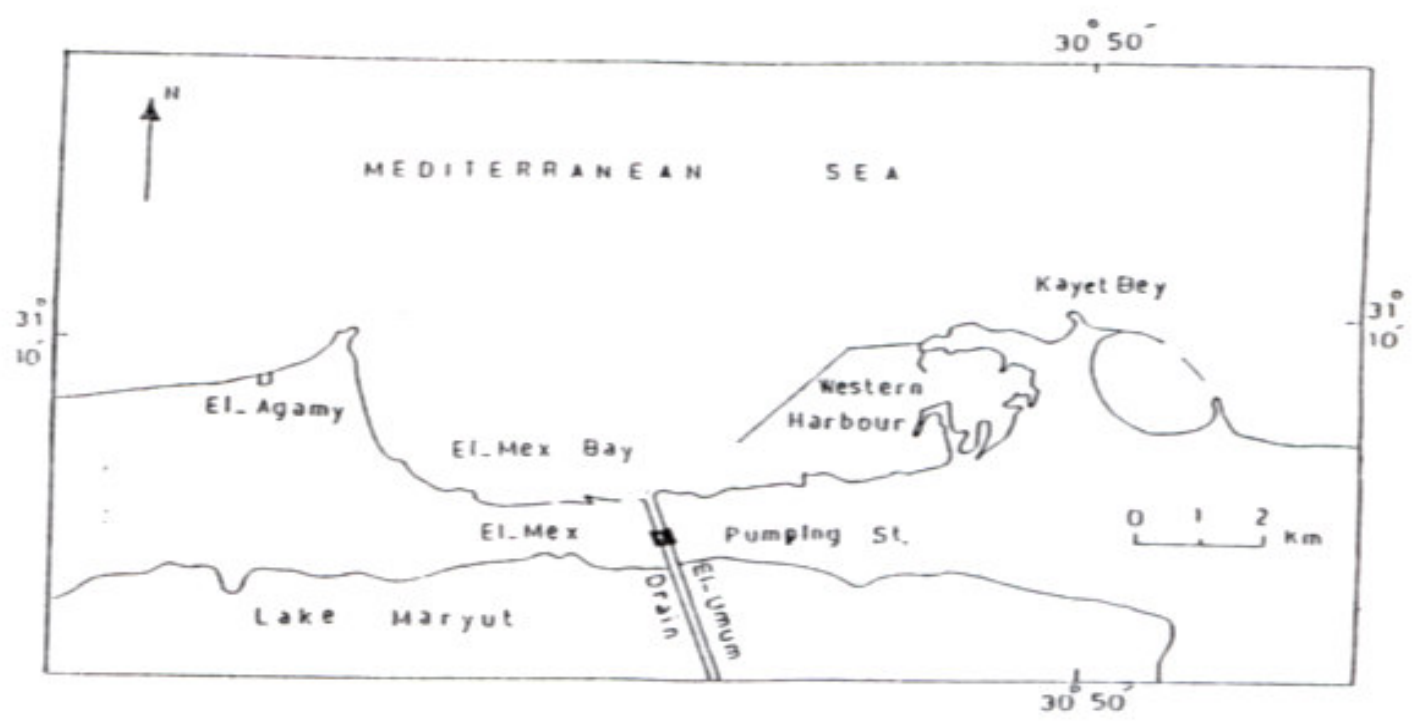

Figure 1 (Abuldahab, et al 1990) 


\section{E.E.Siam}

were taken as analytic sample and digested with concentrated nitric acid inside closed teflon contained in a steel block (bomp). Digested samples were diluted with metals free water and analyzed using a Pye Unicam SP 1900 flame atomic absorption spectrophotometer (AAS). To control the analytical reliability and assure recovery efficiency and accuracy of the results, 7 analyses were conducted on (Mytilus edulis) Standard Reference Material 2974. The laboratory results showed recovery efficiency ranged from $88-101 \%$ for the metals with coefficient of variation $(\mathrm{CV}) 10-14 \%$ for all studied metals.

Table (1): Concentrations of trace metals $\left(\mathrm{mg} \mathrm{kg}^{-1} \mathrm{D}\right.$. Wt) in the tissue organs of five different fish species collected from El-Mex bay area in Dec. 2000

\begin{tabular}{|c|c|c|c|c|c|c|c|c|c|}
\hline Fish species & \begin{tabular}{|l|} 
Fish \\
No
\end{tabular} & $\begin{array}{l}\text { Length } \\
\text { (cm) }\end{array}$ & $\begin{array}{l}\text { Weight } \\
\text { (g) }\end{array}$ & Organ & $\mathrm{Fe}$ & $\mathbf{C u}$ & Mn & $\mathbf{P b}$ & Cd \\
\hline D. Sargus sargus & 9 & $\begin{array}{l}18.3- \\
21.2\end{array}$ & $\begin{array}{l}50.3- \\
60.7\end{array}$ & \begin{tabular}{|l}
$\mathrm{M}$ \\
$\mathrm{L}$ \\
$\mathrm{G}$ \\
$\mathrm{S}$ \\
$\mathrm{B}$ \\
\end{tabular} & \begin{tabular}{|l}
0.3 \\
80.1 \\
10.0 \\
8.3 \\
11.3
\end{tabular} & $\begin{array}{l}0.04 \\
6.6 \\
6.3 \\
10.4 \\
5.6\end{array}$ & \begin{tabular}{|l|}
0.7 \\
3.0 \\
4.8 \\
1.6 \\
4.3 \\
\end{tabular} & $\begin{array}{l}0.8 \\
3.1 \\
2.3 \\
2.1 \\
2.7\end{array}$ & $\begin{array}{l}0.2 \\
1.1 \\
0.4 \\
1.6 \\
1.3\end{array}$ \\
\hline Sparus auratus & 6 & $\begin{array}{l}21.5- \\
25.7\end{array}$ & $\begin{array}{l}175.5- \\
190.2\end{array}$ & $\begin{array}{l}\text { M } \\
\text { L } \\
\text { G } \\
\text { S } \\
\text { B }\end{array}$ & \begin{tabular}{|l}
1.1 \\
11.0 \\
6.9 \\
9.7 \\
10.9
\end{tabular} & $\begin{array}{l}0.3 \\
8.7 \\
1.3 \\
7.5 \\
8.6\end{array}$ & \begin{tabular}{|l|}
0.5 \\
1.1 \\
3.7 \\
5.4 \\
2.9
\end{tabular} & $\begin{array}{l}0.5 \\
1.0 \\
1.2 \\
3.1 \\
2.1\end{array}$ & $\begin{array}{l}0.3 \\
0.2 \\
0.3 \\
0.6 \\
0.8\end{array}$ \\
\hline $\begin{array}{l}\text { Dicrentrachus } \\
\text { punctatus }\end{array}$ & 7 & $\begin{array}{l}20.5- \\
24.5\end{array}$ & $\begin{array}{l}125.5- \\
195.8\end{array}$ & $\begin{array}{l}M \\
L \\
G \\
S \\
B\end{array}$ & \begin{tabular}{|l}
2.4 \\
12.9 \\
5.5 \\
8.2 \\
15.5
\end{tabular} & $\begin{array}{l}0.7 \\
3.3 \\
1.8 \\
8.7 \\
7.1\end{array}$ & \begin{tabular}{|l|}
1.3 \\
2.2 \\
2.4 \\
3.6 \\
5.5
\end{tabular} & \begin{tabular}{|l|}
0.8 \\
1.5 \\
1.4 \\
2.9 \\
2.9
\end{tabular} & $\begin{array}{l}0.1 \\
0.8 \\
0.3 \\
0.8 \\
1.5\end{array}$ \\
\hline Mugil capito & 8 & $\begin{array}{l}21.7- \\
24.4\end{array}$ & $\begin{array}{l}80.2- \\
98.5\end{array}$ & $\begin{array}{l}M \\
L \\
G \\
S \\
B\end{array}$ & $\begin{array}{l}1.2 \\
11.1 \\
7.4 \\
11.3 \\
16.4\end{array}$ & $\begin{array}{l}0.5 \\
6.1 \\
1.7 \\
2.9 \\
6.6 \\
\end{array}$ & \begin{tabular}{|l|}
1.1 \\
2.6 \\
5.6 \\
2.1 \\
4.5
\end{tabular} & \begin{tabular}{|l|}
0.4 \\
0.9 \\
1.1 \\
1.2 \\
3.0
\end{tabular} & $\begin{array}{l}0.1 \\
0.2 \\
0.2 \\
0.4 \\
1.4\end{array}$ \\
\hline Siganus rivulatus & 9 & $\begin{array}{l}385- \\
45.4\end{array}$ & $\begin{array}{l}45.5- \\
60.0\end{array}$ & $\begin{array}{l}\mathrm{M} \\
\mathrm{L} \\
\mathrm{G} \\
\mathrm{S} \\
\mathrm{B}\end{array}$ & $\begin{array}{l}2.8 \\
11.7 \\
10.1 \\
13.8 \\
9.6\end{array}$ & $\begin{array}{l}0.2 \\
9.8 \\
5.9 \\
5.0 \\
5.7\end{array}$ & \begin{tabular}{|l|}
1.5 \\
6.5 \\
5.8 \\
5.0 \\
3.3 \\
\end{tabular} & $\begin{array}{l}0.9 \\
1.0 \\
3.2 \\
3.5 \\
2.5\end{array}$ & $\begin{array}{l}0.4 \\
0.2 \\
0.6 \\
1.7 \\
1.1\end{array}$ \\
\hline
\end{tabular}


Table (2): Ratios of metal concentration in different organs to that in muscle tissues of the fish.

\begin{tabular}{|c|c|c|c|c|c|c|c|}
\hline Fish species & Feeding & $\begin{array}{l}\text { Organ/ } \\
\text { muscle }\end{array}$ & $\mathbf{F e}$ & $\mathbf{C u}$ & Mn & $\mathbf{P b}$ & Cd \\
\hline D. $\operatorname{sargus}^{(a)}$ & $\begin{array}{l}\text { Crustacea, } \\
\text { molluscus \& fishes }\end{array}$ & $\begin{array}{l}\mathrm{L} / \mathrm{M} \\
\mathrm{G} / \mathrm{M} \\
\mathrm{S} / \mathrm{M} \\
\mathrm{B} / \mathrm{M}\end{array}$ & $\begin{array}{l}267.0 \\
33.3 \\
27.6 \\
37.6\end{array}$ & $\begin{array}{l}165.0 \\
157.5 \\
260.0 \\
140.0\end{array}$ & $\begin{array}{l}4.3 \\
6.9 \\
2.3 \\
6.1\end{array}$ & $\begin{array}{l}3.9 \\
2.9 \\
2.6 \\
3.4\end{array}$ & $\begin{array}{l}5.5 \\
2.0 \\
8.0 \\
6.5\end{array}$ \\
\hline S. auratus $(a)$ & $\begin{array}{l}\text { Molluscus, } \\
\text { crustacea, worms }\end{array}$ & $\begin{array}{l}\mathrm{L} / \mathrm{M} \\
\mathrm{G} / \mathrm{M} \\
\mathrm{S} / \mathrm{M} \\
\mathrm{B} / \mathrm{M}\end{array}$ & $\begin{array}{l}10.0 \\
6.3 \\
8.8 \\
9.9\end{array}$ & $\begin{array}{l}29.0 \\
4.3 \\
25.0 \\
28.7\end{array}$ & $\begin{array}{l}2.2 \\
7.3 \\
10.8 \\
5.8 \\
\end{array}$ & $\begin{array}{l}2.0 \\
2.4 \\
6.2 \\
4.2\end{array}$ & $\begin{array}{l}0.7 \\
1.0 \\
2.0 \\
2.7\end{array}$ \\
\hline D. punctatus $(a)$ & $\begin{array}{l}\text { Small shoaling } \\
\text { fish, \& wide range } \\
\text { of invertebrate as } \\
\text { shrimps, brown } \\
\text { crabs, \& squids }\end{array}$ & $\begin{array}{l}\mathrm{L} / \mathrm{M} \\
\mathrm{G} / \mathrm{M} \\
\mathrm{S} / \mathrm{M} \\
\mathrm{B} / \mathrm{M}\end{array}$ & $\begin{array}{l}5.4 \\
2.3 \\
3.4 \\
6.5\end{array}$ & $\begin{array}{l}4.7 \\
2.6 \\
12.4 \\
10.1\end{array}$ & $\begin{array}{l}1.7 \\
1.8 \\
2.8 \\
4.2\end{array}$ & $\begin{array}{l}1.9 \\
1.8 \\
3.6 \\
3.6\end{array}$ & $\begin{array}{l}8.0 \\
3.0 \\
8.0 \\
10.0\end{array}$ \\
\hline M. capito $^{(a)}$ & $\begin{array}{|lr|}\text { Minute r bottom } \\
\text { living planktonic } \\
\text { organism, and on } \\
\text { suspended matter }\end{array}$ & $\begin{array}{l}\mathrm{L} / \mathrm{M} \\
\mathrm{G} / \mathrm{M} \\
\mathrm{S} / \mathrm{M} \\
\mathrm{B} / \mathrm{M}\end{array}$ & $\begin{array}{l}9.3 \\
6.2 \\
9.4 \\
13.7\end{array}$ & $\begin{array}{l}12.2 \\
3.4 \\
5.8 \\
13.2\end{array}$ & $\begin{array}{l}2.4 \\
5.1 \\
1.9 \\
4.1 \\
\end{array}$ & $\begin{array}{l}2.3 \\
2.8 \\
3.0 \\
7.5\end{array}$ & $\begin{array}{l}2.0 \\
2.0 \\
4.0 \\
14.0\end{array}$ \\
\hline S. rivulatus $(b)$ & Algae, diatoms & $\begin{array}{l}\mathrm{L} / \mathrm{M} \\
\mathrm{G} / \mathrm{M} \\
\mathrm{S} / \mathrm{M} \\
\mathrm{B} / \mathrm{M}\end{array}$ & $\begin{array}{l}4.2 \\
3.6 \\
4.9 \\
3.4 \\
\end{array}$ & $\begin{array}{l}49.0 \\
29.5 \\
25.0 \\
28.5\end{array}$ & $\begin{array}{l}4.3 \\
3.9 \\
3.3 \\
2.2 \\
\end{array}$ & $\begin{array}{l}1.1 \\
3.6 \\
3.9 \\
2.2 \\
\end{array}$ & $\begin{array}{l}0.5 \\
1.5 \\
4.3 \\
2.8 \\
\end{array}$ \\
\hline
\end{tabular}

(a): Carnivorous fish

(b): Herbivorous fish

Table (3): Comparison between trace metals concentrations $\left(\mathrm{mg} \mathrm{kg}^{-1}\right)$ in muscles of the fish from El-Mex Bay and from elsewhere in the Mediterranean Sea.

\begin{tabular}{|c|c|c|c|c|c|c|}
\hline Fish & $\mathbf{F e}$ & $\mathrm{Cu}$ & Mn & $\mathbf{P b}$ & Cd & Reference \\
\hline \multirow[t]{5}{*}{ Sparus auratus } & 11 & 0.3 & 0.5 & 0.5 & 0.3 & Present study \\
\hline & 5.03 & N.D & 0.05 & 0.71 & 0.1 & (1) \\
\hline & 19.0 & 9.5 & 2.0 & - & 0.14 & \multirow{3}{*}{$(2)$} \\
\hline & 62.0 & 7.1 & 3.0 & - & 0.54 & \\
\hline & 24.0 & 4.0 & 4.0 & - & 0.23 & \\
\hline Mugil capito & 1.2 & 0.5 & 1.1 & 0.4 & 0.1 & Present study \\
\hline Mugil spp. & \multirow{2}{*}{$\begin{array}{l}35.0-48.0 \\
(41.5) \\
3.9-15.7 \\
(9.8)\end{array}$} & \multirow{2}{*}{$\begin{array}{l}0.16-.0 .31 \\
(0.23) \\
0.69-1.11 \\
(0.9)\end{array}$} & \multirow{2}{*}{$\begin{array}{l}0.26-0.42 \\
(0.34) \\
0.27-0.65 \\
(0.46)\end{array}$} & \multirow{2}{*}{$\begin{array}{l}1.91 \\
(2.46) \\
2.9-3.2 \\
(3.05)\end{array}$} & \multirow{2}{*}{$\begin{array}{l}\text { N.D } \\
0.17-0.26 \\
(0.215)\end{array}$} & (3) \\
\hline (Bay of Izmir) & & & & & & (4) \\
\hline $\begin{array}{l}\text { M. auratus } \\
\text { (Aegean coast) }\end{array}$ & - & $5.1-90$ & $5.2-8.1$ & $12.5-18.0$ & - & (5) \\
\hline Siganus rivlatus & $\begin{array}{l}2.8 \\
0.05 \\
- \\
78.2 \pm 4.4\end{array}$ & $\begin{array}{l}0.2 \\
\text { N.D } \\
8.0 \\
0.29 \pm 0.02\end{array}$ & $\begin{array}{l}1.5 \\
0.05 \\
- \\
0.82 \pm 0.07\end{array}$ & $\begin{array}{l}0.9 \\
0.44 \\
0.60 \\
0.67 \pm 0.03\end{array}$ & \begin{tabular}{|l|}
0.4 \\
0.02 \\
0.023 \\
N.D
\end{tabular} & $\begin{array}{l}\text { Present study } \\
(1) \\
(6) \\
(3)\end{array}$ \\
\hline
\end{tabular}

ND: not detected.

(1) Shriadah and Emara (1992)

(2) Ezzat et al., (1985)

(3) Emara et al. (1993)

(4) Uysal and Tuncer (1982)

5)Uysal (1980)

(6)El-Nabawi

et al (1987) 


\section{E.E.Siam}

Table (4): Mean concentrations of the studied trace metals in the fish muscles and their percentage to the provisional tolerable (PTWI).

\begin{tabular}{|c|c|c|c|c|c|c|}
\hline \multirow[t]{2}{*}{ Fish species } & \multicolumn{3}{|c|}{\begin{tabular}{|l|} 
Mean \\
concentration \\
$(\mathrm{mg} / \mathrm{kg})$
\end{tabular}} & \multicolumn{3}{|c|}{$\begin{array}{l}\text { \% of the present } \\
\text { concentrations to that of } \\
\text { PTWI }\end{array}$} \\
\hline & $\mathrm{Cu}$ & $\mathbf{P b}$ & Cd & $\mathrm{Cu}$ & $\mathbf{P b}$ & Cd \\
\hline D. Sargus sargus & 0.04 & 0.8 & 0.2 & 0.002 & 3.29 & 7.67 \\
\hline Sparus auratus & 0.30 & 0.5 & 0.3 & 0.014 & 2.05 & 11.50 \\
\hline Dicentrachus punctatus & 0.70 & 0.8 & 0.1 & 0.033 & 3.29 & 3.83 \\
\hline Mugil capito & 0.50 & 0.4 & 0.1 & 0.023 & 1.64 & 3.83 \\
\hline Siganus rivulatus & 0.20 & 0.9 & 0.4 & 0.009 & 3.70 & 15.34 \\
\hline
\end{tabular}

Calculated PTWI values $\mathrm{Cu}, \mathrm{Pb}$ and $\mathrm{Cd}$ are $2121,24.3$ and $2.6 \mathrm{mg} / 70 \mathrm{~kg}$ man, respectively.

\section{Results and Discussion}

The analytical results $(\mathrm{mg} / \mathrm{kg}$ on the dry weight basis), of the trace metals ( $\mathrm{Fe}, \mathrm{Mn}, \mathrm{Cu}, \mathrm{Pb}$ and $\mathrm{Cd}$ ) in the muscle tissues and in different organs (liver, brain, stomach and gills) of the studied five Mediterranean fish species are shown in Table 1. A perusal of this table shows in all the tested fish species, high accumulation of these metals in different organs, with respect to those in the muscle tissues. Iron was the more dominant one among in the studied metals. Same results were also noticed by Vigh et al (1996) where trace metals were concentrated in kidney and liver than in muscle and gut of the fish. Also, $\mathrm{Fe}$ was of higher concentration compared to the toxic metals $(\mathrm{Pb}$ and $\mathrm{Cd}$ ) in muscle tissue in all studied fish with the exception of D. sargus fish. Also, from Table 1, Fe, $\mathrm{Cu}$ and $\mathrm{Mn}$ concentrations were higher than those of the toxic metals $\mathrm{Pb}$ and $\mathrm{Cd}$ in all fish studied. These results are in accordance with the findings of Matta et al (1999) where, Fe was the most abundant one followed by $\mathrm{Cu}$ and $\mathrm{Cd}$ but in fish barracuda (Sphyraena argentea) liver.

Brain and gills of the tested fish (Table 1) gained a high level (10.9-88.1 $\mathrm{mg} / \mathrm{kg}$ ) of Fe than other metals in all studied fish except of Sigarus rivulatus where stomach had the highest $\mathrm{Fe}$ content $(13.8 \mathrm{mg} / \mathrm{kg})$. The increased concentration of the essential metals ( $\mathrm{Fe}, \mathrm{Cu}$ and $\mathrm{Mn}$ ) reflects the increasing trophic level of the fish, as these metals are required metabolically by living organisms and the concentrations in the tissues may be actively regulated by these fish. The average concentrations of $\mathrm{Cu}$ in fish muscle and organs are shown in Table 1, that the lower concentration was found in muscle tissue where it was in the range 0.04-0.7 $\mathrm{mg} / \mathrm{kg}$ dry weight. In addition, brain, stomach and liver showed high $\mathrm{Cu}$ level in all fish studied. It was also noted that D. sargus contained the highest level of $\mathrm{Cu}(10.4 \mathrm{mg} / \mathrm{kg})$ in their stomach. These results are in line with that recorded by Moore and Ramamoorthy (1984), they reported that residues of copper in muscle tissue are low, and frequently decline with age and size of fish.

The concentrations of the toxic metal $\mathrm{Pb}$ and $\mathrm{Cd}$ were generally higher in fish organs than that detected in their muscles (Table 1). Lead concentration ranged between 1.2 and $3.5 \mathrm{mg} / \mathrm{kg}$ in the stomach while it ranged from 0.4$0.9 \mathrm{mg} / \mathrm{kg}$ in fish muscles. Also, brain had a high $\mathrm{Pb}$ concentration (2.1-3.0 $\mathrm{mg} / \mathrm{kg}$ ). These results agreed well with a study carried out by Zauke et al (1999) who stated that, concentration of $\mathrm{Pb}$ and $\mathrm{Ni}$ are below limits of detection 
in liver and muscles tissues of 15 marine species collected from Barents Sea.

Lead residues were detected in all fish samples collected (Table 1). The levels of $\mathrm{Pb}$ in muscle tissue are usually lower than those in organs. This may be explained by the relatively low rate of binding to $\mathrm{SH}$ groups (Moore and Ramamoorthy, 1984).

Cadmium concentration was generally lower than $\mathrm{Pb}$ concentration in various organs and its range is between $0.1-1.7 \mathrm{mg} / \mathrm{kg}$ also gills showed the lowest concentration as compared to other organs (Table 1). These results are not in line with that recorded by Sangalang and Freeman (1979) who found that, gills and the posterior kidney revealed a high metal content than other tissue. Also, stomach, brain and liver showed nearly the same concentration in various fish species (Table 1). These results agree with Romeo et al (1999) who declared that, $\mathrm{Cd}$ and $\mathrm{Cu}$ were present in low level in the muscle and gills and higher levels are encountered in the livers. On the other hand, toxic metals such as $\mathrm{Pb}$ and $\mathrm{Cd}$ have higher values in the stomach of the herbivorous fish Siganus rivulatus than carnivorous fishes (Table 1 and 2).

The obtained results in Table 2 indicate that the concentrations of trace metals are usually higher in organs than muscle tissue. For example, the liver: muscle ratio of cadmium for $D$. sargus and Dicentrachus punctatus were 5.5:1 and 8.0:1 respectively. A study by Mackay et al (1975) showed that the ratio of mercury in the liver:muscle in block marlin collected from Australia was 1.4:1. Also, a high organ:muscle ratio was observed in $\mathrm{Cu}$ concentration in D. sargus sargus where it were $165: 1,157.5: 1,260: 1$ and 140:1 in liver, gills, stomach and brain respectively (Table 2). These results are in same line with El Nabawi et al., (1987) who detected that total residue are slightly higher in organs than in muscle tissue, for $\mathrm{Hg}$, and $\mathrm{Cd}$. In addition: the stomach : muscle ratio of $\mathrm{Pb}$ was high in Sparus auratus, Dicentrachus punctatus and Siganau rivulatus where these were 6.2 : 1, 3.6 : 1 and $3.9: 1$ respectively. Table (2) indicated also that the ratio of concentration of $\mathrm{Pb}$ of organs with that of muscle tissues was lower, while $\mathrm{Cu}$ ratios showed the highest values. Also $\mathrm{Cu}$ concentration ratios of $D$. sargus was higher than other elements where stomach ratio : muscle ratio was $260: 1$.

Results in Table (3) shows a comparison between trace metals concentration $(\mathrm{mg} / \mathrm{kg})$ in fish muscle in the present study with their correspondings reported elsewhere in the Mediterranean Sea. This table shows that, the level of concentration of $\mathrm{Fe}$ in the muscles of Mugil species was 1.2 $\mathrm{mg} / \mathrm{kg}$. This was lower than that found by Emara et al (1993) and Uysal and Tuncer (1982) (41.5 and $9.8 \mathrm{mg} / \mathrm{kg}$, respectively, Table 3 ). On the other hand, the level of $\mathrm{Cu}$ and $\mathrm{Mn}(0.5$ and $1.1 \mathrm{mg} / \mathrm{kg}$ respectively) in Mugil muscle were higher than what has been found by Emara et al (1993), (0.23 and $0.34 \mathrm{mg} / \mathrm{kg}$ respectively). Lead concentration in muscle of Mugil capito was $0.4 \mathrm{mg} / \mathrm{kg}$, which is lower than what is reported by Emara at al (1993) and Uysal (1980), ( $\mathrm{Pb}$ concentrations were 2.46 and $3.05 \mathrm{mg} / \mathrm{kg}$ respectively). The table also shows that $\mathrm{Cd}$ concentration of Mugil muscle was 0.1 $\mathrm{mg} / \mathrm{kg}$ that agrees well with that of Uysal and Tuncer (1982). Concentration of $\mathrm{Fe}$ in muscles of Siganus rivulatus was $2.8 \mathrm{mg} / \mathrm{kg}$, it is higher than the value recorded by Shriadah and Emara (1992), (Fe concentration was 0.05 $\mathrm{mg} / \mathrm{kg}$ ). Emara et al (1993) detected a high level of $\mathrm{Fe}$ concentration in muscles of Siganus luridus (78.2 


\section{E.E.Siam}

$\mathrm{mg} / \mathrm{kg}$ ). Also Mn concentration (1.5 $\mathrm{mg} / \mathrm{kg}$ ) was higher than that reported by Shriadah and Emara (1992) and Emara et al (1993) where Mn concentrations were 0.05 and $0.82 \mathrm{mg} / \mathrm{kg}$ respectively. Copper concentration in Siganus muscles was $0.2 \mathrm{mg} / \mathrm{kg}$. This concentr ation is lower than the value $(8 \mathrm{mg} / \mathrm{kg})$ reported by El Nabawi et al (1987). The concentration of the toxic metals $\mathrm{Pb}$ and $\mathrm{Cd}$ in muscles of Siganus species were 0.9 and $0.4 \mathrm{mg} / \mathrm{kg}$ respectively. These results are higher than what has been found by Shriadah and Emara (1992) and El Nabawi et al (1987).

The results in Table (3) indicated that, all fish studied did not enrich the metals to dangerous levels compared with that found e.g. in Bay Izmir (Uysal and Tuncer, 1982). At the same time the present results revealed the presence of a high level of $\mathrm{Cd}$ particularly in the fish organs with respect to those of Health Standards levels $(0.5 \mathrm{mg} / \mathrm{kg})$ established by US National Academy of Science (1972). So far in many countries there are no maximum allowable limits for such toxic metals $\mathrm{Cd}$ and $\mathrm{Pb}$ in the edible parts of fish (Falandysz, 1985). However, the recommendations of National Health and Medical Research Council of Australia (NHMRC) specify that, the concentrations of $\mathrm{Cd}$ and $\mathrm{Pb}$ in the edible parts of fish should not exceed $2.0 \mathrm{mg} / \mathrm{kg}$ (Bebbington et al, 1977). In contrast to NHMRC level, the Western Australian Food and Drug Regulations gave concentrations of 5.5 and $40 \mathrm{mg} / \mathrm{kg}$ for $\mathrm{Cd}$ and $\mathrm{Zn}$ respec tively as reported by Plaskett and Potter (1979). Although most of the fish samples in the present study showed $\mathrm{Cd}$ levels closed to that of the NHMRC (2.0 $\mathrm{mg} / \mathrm{kg}$ ) in their organs, non-of them contained $\mathrm{Cd}$ concentrations in their muscle tissues exceeding $0.5 \mathrm{mg} / \mathrm{kg}$.
The risk to man from consum ption of metals in fish has been discussed by Bernhard (1982). This can be estimated by comparing the metal intake from an observed consumption rate of fish with a Provisional Tolerable Weekly Intake (PTWI), for the metals $\mathrm{Pb}, \mathrm{Cu}$ and $\mathrm{Cd}$. The respective PTWI values for these three metals were calculated to be $24.5,2121$ and $2.6 \mathrm{mg}$ per $70 \mathrm{~kg}$ man. An estimation for the percentage of the concentrations obtained in the present study to that of these metals was made and listed in (Table 4). This table demonstrates that, the concentration of these metals in fish would be extremely lower than PTWI values and accordingly, the human consumption of fish caught from the Alexandria region is safe. Therefore, it does not pose a health hazard, but protection of the aquatic environment is warranted to preserve this important part of the traditional diet. Moreover, regular monitoring of pollutants in fish and other biota are essential from the point of view environmental toxicology and set database for these researches.

\section{References}

1. Abuldahab, O. Khalil, A.N. and Halim Y. Chromium flues through Mex Bay inshore waters. Mar. Poll. Bull. 1990, 21: 68-73.

2. (APHA), Standard methods for examination of water and waste water. $16^{\text {th }}$ Ed. Washington, D.C. 1985; 1268.

3. Barelli $\mathbf{M}$ : Heavy metal distribution in different fish species from the Mauritania coast. Sci total Environ; 232 : 169-75 1999 Aug I.

4. Bebbington GN, Mackay NJ, Chvoika R, William RJ, Dunn A, Auty EH. Heavy metals selenium and arsenic in nine species of Australian commercial fish. Aust J Mar Freshwater Res ; 1977, 28: 277-86.

5. Bernhard M. Manual of methods of 
aquatic environment research: Sampling and analysis of biological materials. Rome: FAO Fisheries Tech Paper No 158 FIRI/TI58 1976; part3:123, Rome

6. Bernhard, M. Levels of trace metals in the Mediterranean (Review paper) $\mathrm{VI}^{\mathrm{es}}$ Journees Elud. Pollutions, Cannes, CIESM, 1982, PP 237-243.

7. El-Nabawi A, Heinzow B, Kruse H: $\mathrm{As}, \mathrm{Cd}, \mathrm{Cu}, \mathrm{Pb}, \mathrm{Hg}$ and $\mathrm{Zn}$ in fish from the Alexandria region. Bull Environ Contam Toxicol 1987; 39: 889-97.

8. El-Rayis, O. A., Halim, Y. and Abuldahab, O. Total mercury in the coastal marine ecosystem west Alexandria. FAO Fish Rep. (325), 1986, 58-73.

9. El-Rayis, O. A., Abuldahab, O., Halim, Y. and Riley, J.P. Heavy metals in some food chain organisms from ElMex Bay, West of Alexandria Egypt. Egypt Proc. $7^{\text {th }}$ Int. Conf. Environ. Prot. is a Must NIOF and ISA, 1997, 26-35.

10. El-Sokkary I.H. Mercury accumu lation in fish from the Mediterranean coastal area of Alexandria, Egypt. Journees Etud. Poll., Caliari, C.I.E.S.M., 1980, 493-496.

11. Emara H. I. Study of some heavy metals in Abu-Qir Bay and Lake Edku. $\mathrm{V}^{\mathrm{es}}$ Journees Etud Poll Cannes, CIESM 1982, 395-399.

12. Emara HI, El-Deek MS, Ahmed NS. Comparative study on the levels of trace metals in some Mediterranean and Red Sea fishes. Chem and Ecology 1993; 8: 119-127.

13. EPA. Draft Fish Sampling and Analysis: A Guidance Document for Issuin Fish Advisories Washington, DC. 1991, 20460.

14. Ezzat A., El-Rayis O. and El-Nady, F. Bioaccumulation of some heavy metals in coastal marine animals in vicinity of Alexandria, Egypt. I-Surveying. 1985. Fac. Mar. Sc., Jeddah, Vol. 4, 157-165.

15. Falandysz J. Trace metals in flat fish from the southern Baltic Z. Lebensem Unters Forsch 1985; 181: 117-120.

16. Mackay N.S, Kazacos N.M, Williams RJ, Leedow MI. Selenium and heavy metals in black marlin. Marine Pollut Bull 1975, 6: 57-60.

17. Matta J; Milad M, Manger R., Tosteson T. Heavy metals, lipid peroxidation, and ciguatera toxicity in the liver of the caribbean barracuda (sphyraena barracuda). Biol Trace Elem Res, 1999, 70: 69-79.

18. Moore J.W, Ramamoorsthy S. Heavy metals in natural waters. Springerverlag, New York 1984, 268 PP.

19. Morales MIN B. Determination of trace elements in otoliths of sea fish reared in tanks. Journees Etud Poll Cagliari CIESM 1980, 369-372.

20. National Academy of Sciences, National Academy of Engineering (1972). Section III - Freshwater aquatic life and wildlife, and Section IV Marine aquatic life and wildlife. Pages 106-296 in water quality Criteria. Ecological ResreachSeries, EPA R373-033, March 1973, NAS, Washinton, DC.

21. Plaskett D, Potter JC. Heavy metal concentrations in the muscle tissue of 12 species of teleost from Cockburn Sound, Western Australia. Aust J Mar Freshwater Res 1979; 30: 609-616.

22. Romeo M; Sian Y; Sidoumou Z, Gnassia. Barelli M: Heavy metal distribution in different fish species from the Mauritania coast. Sci total Environ, 1999, Aug I 232: 169-75.

23. Sangalang, G.B \& Freeman, H.C. Tissue uptake of cadmium in brook trout during chronic sublethal exposure. Arch.environ. contam toxical; 1979, 8. 77-84.

24. Shriadah MMA, Emara H.I. Iron, manganese, Nickel, lead and cadmium in fish and crustacea from the Eastern harbour and El-Mex Bay of Alexandria. Bull High Inst Public Health 1992; 22 (3): 515-525.

25. Tayel, F.T.R. Trace metals concentrations in the muscle tissue of ten fish species from Abu-Qir Bay, Egypt. International Journal of Environmental Health Research, 1995, Vol.5, (4), pp.321-328.

26. UNEP / FAO / IAEA / IOC: 


\section{E.E.Siam}

Determination of total cadmium, zinc, lead and copper in selected marine organisms by flameless atomic absor ption spectrophotometry. Reference methods for marine pollution studies. 1984, No.11, Rev.1.

27. Uysal H. Levels of trace elements in some food chain organisms from the Acgcan coasts. Journees Etud Poll Cagliari CIESM 1980, 503-512.

28. Uysal H, Tuncer S. levels of heavy metals in some commercial food species in the Bay of Izmir (Turkey). $\mathrm{V}^{\mathrm{es}}$ Journees Etud Poll Cannes CIESM 1982, 323-327.

29. USA-National Academy of Sciences, National Academy of Engineering.
Section III- Freshwater aquatic life and wildlife, and Section IV- Marine aquatic life and wildlife 1972: 106-296. In: Water Quality Criteria. Ecological Research Series, EPA-R3-73-033, March 1973, NAS, Washington DC.

30. Vigh P; Mastala Z; Balogh KV: Comparisons of heavy metal concentration of grass carp in a shallow eutrophic lake and a fishpond (possible effects of food contamination). Chemosphere, 1996 Feb, 32: 691-701.

31. Zauke GP, Savinov VM; Ritterhoff J; Savinova T: Heavy metals in fish from the Barents Sea, Sci Total Enviro.1999, 227: 161-73. 


\title{
تقييم تركيز المعادن الثقيلة فى بعض اسماك شواطى الإسكندرية
}

\author{
د/ إيمان إبر اهيم صيام \\ أستاذ مساعد ببرنامج حماية البيئة ـ الأكاديمية العربية إيمية للعلوم و التكنولوجيا

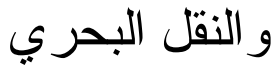

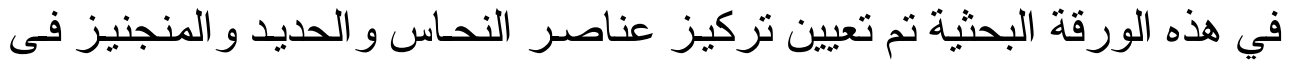

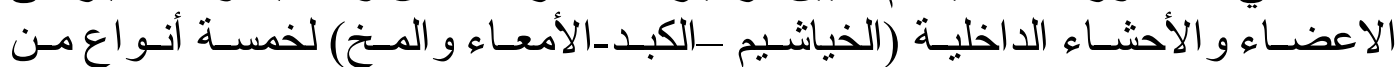

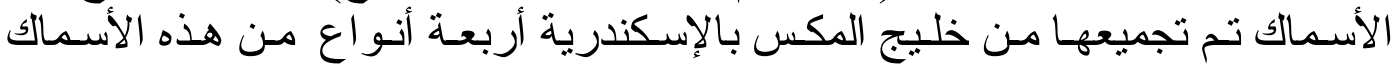

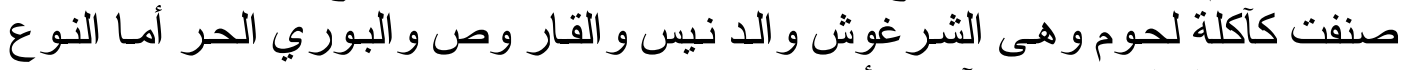
الخامس(البطاطا) فهو من وآكل الأعشاب.

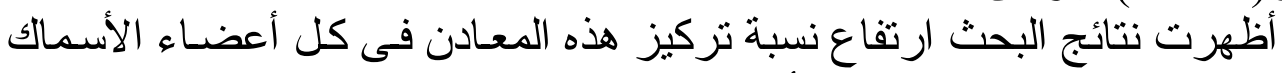

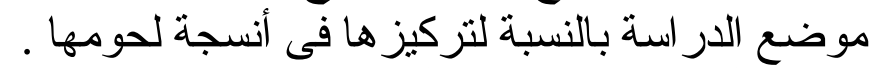

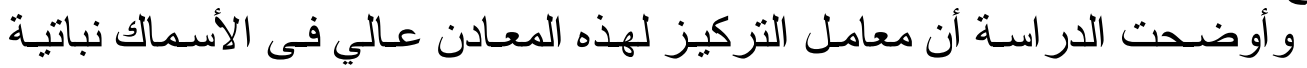

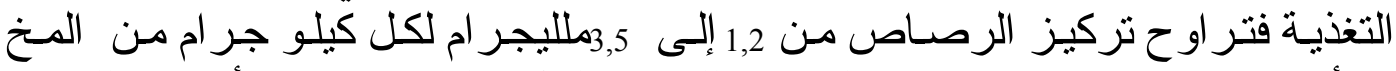

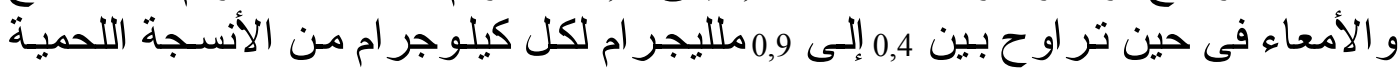

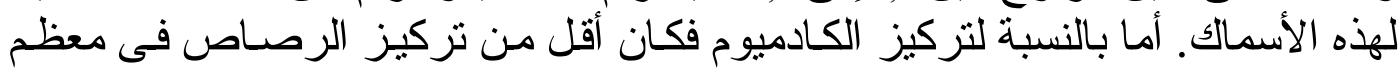

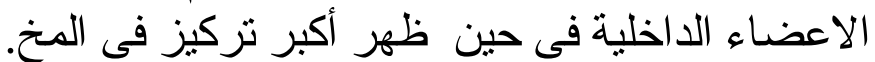

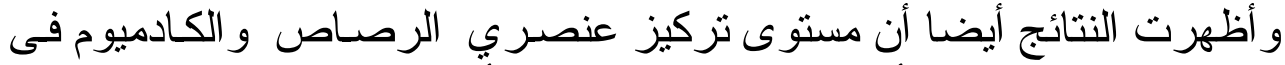

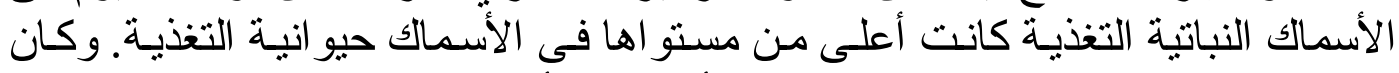

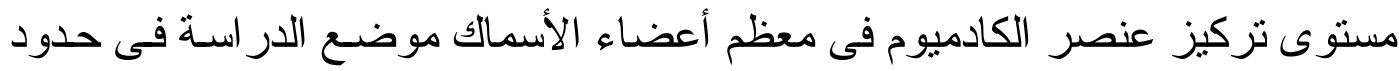

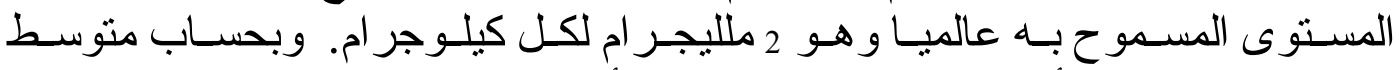
استهلاك الفرد من الأسماك موضع الدر اسة نجد أن نسبة مايدخل جسم الإنسان من هذابه

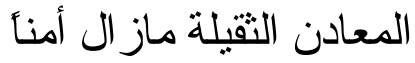

